\section{Karolina Olszewska}

Uniwersytet Mikołaja Kopernika w Toruniu

karolina_olszewska90@wp.pl

ORCID 0000-0003-2192-896X

DOI: http://dx.doi.org/10.12775/BPTh.2021.021
Biblica

et

Patristica

Thoruniensia
14 (2021) 4: 401-418

ISSN (print) 1689-5150

ISSN (online) 2450-7059

\title{
Użycie Księgi Koheleta w Ewangelii wg św. Łukasza
}

\section{The Use of Qoheleth in the Gospel of Luke}

Streszczenie. W Łk można wskazać osiem fragmentów, w których widoczne są odniesienia do Koh $(2,40.52 ; 8,5-8 \mathrm{a} ; 8,25.35 ; 11,42 ; 12,2-3 ; 12,19 ; 12,20 ; 12,25)$. Najczęściej w passusach trzeciej ewangelii można widzieć echo słów zapisanych przez Eklezjastesa. Nie jest to jednak jedyny rodzaj związku zachodzący pomiędzy tymi tekstami. W Koh 1,16 bohater przedstawiony jako Salomon może być typem Jezusa pokazanego w Łk 2,40.52. W Łk 12,19 można widzieć natomiast prawdopodobną aluzję do Koh 8,15. Użycie typologii, aluzji i ech w zaprezentowanych powyżej fragmentach wpisuje się w badanie zależności intertekstualnych pomiędzy tekstami. Autor trzeciej ewangelii poprzez użycie Koh dokonuje jego reinterpretacji.

Abstract. There are eight passages in the Gospel of Luke in which references to the Book of Qoheleth are visible $(2: 40.52 ; 8: 5-8 \mathrm{a} ; 8: 25.35 ; 11: 42 ; 12: 2-3 ; 12: 19 ; 12: 20 ; 12: 25)$. Most often, in the passages of the Third Gospel, one can see an echo of the words written by Ecclesiastes. However, this is not the only type of connection between these two texts. In Qoh 1:16, the hero depicted as Solomon may be the type of Jesus from Lk 2: 40,52. In Luke 12:19, however, a possible allusion to Qoh 8:15 can be observed, as well. The use of typology, allusions, and echoes in the aforementioned passages is part of the study of intertextual relationships between these texts. The author of the Third Gospel, using Qoheleth, reinterprets it.

Słowa kluczowe: reinterpretacja; aluzja; Kohelet; Ewangelia wg św. Łukasza; użycie Starego Testamentu w Nowym.

Keywords: reinterpretation; allusion; Qoheleth; Gospel of Luke; the New Testament use of the Old Testament. 
Tytuł niniejszego artykułu sugeruje, że zostanie w nim, w jakiejś mierze, poruszony problem intertekstualności, czyli relacji jaka zachodzi pomiędzy tekstami ${ }^{1}$. Badacze zajmujący się intertekstualnością w Piśmie Świętym, chcą ustalić, w jaki sposób Stary Testament oddziaływał na autorów Nowego Testamentu. Sam fakt użycia ST przez autorów drugiej części Pisma Świętego pokazuje, że traktowali oni ST jako źródło zarówno w znaczeniu literackim, jak i teologicznym² ${ }^{2}$.

Niniejszy artykuł zajmie się użyciem Księgi Koheleta w Ewangelii wg św. Łukasza. Zostaną w nim najpierw omówione pewne założenia metodologiczne, następnie przedstawiony będzie wykaz tekstów Łk, w których może być użyty Koh, a na końcu zostanie zaprezentowana i poddana analizie możliwa zależność między Łk a Koh i wskazane będą pewne przesłanki teologiczne wypływające $\mathrm{z}$ tych tekstów.

\section{Założenia metodologiczne}

Pierwszym problemem metodologicznym, który należy podjąć jest stwierdzenie czy Łukasz pisząc swoją ewangelię wykorzystywał tekst Septuaginty (dalej: LXX) czy Biblii Hebrajskiej (dalej: BH). Podążając za założeniami dokonanymi przez K. Mielcarka $\mathrm{z}$ dużą dozą prawdopodobieństwa można stwierdzić, że Łukasz był pod silnym wpływem LXX ${ }^{3}$. Nie da się wykluczyć, że korzystał z tekstów semickich, ale jak zauważa K. Milecarek, niektórzy „wolą w semityzmach widzieć septuagintyzmy" ". Ewangelista świadomie naśladował styl LXX. Celowo konstruował swój tekst w taki sposób, aby każdy jego fragment był wygładzony i dostosowany do całości jego dzieła zgodnie z ogólną tendencją kanonów literackich klasycznej greki. Autor wkładał taki wysiłek redakcyjny i naśladował styl LXX, aby podkreślić jedność historii przedstawianej w Starym i Nowym Testamencie, a także po to, aby, za Filonem Aleksandryjskim, ukazać LXX jako

1 Por. J. Nawrot, Aluzje literackie w teologicznej ocenie, s. 7; zob. R. Nycz, Intertekstualność i jej zakresy, s. 95-116.

2 Por. D. Kotecki, Aluzje do Księgi Sofoniasza, s. 108.

3 Zob. K. Mielcarek, Język Septuaginty, s. 33-47. W tym artykule autor przedstawia w sposób syntetyczny całą historię dyskusji na temat zależności trzeciej ewangelii od LXX i różnych tekstów semickich.

4 Por. ibidem, s. 41. 
tekst natchniony ${ }^{5}$. W niniejszym artykule również LXX zostanie przyjęta jako główny tekst źródłowy dla możliwego użycia przez trzeciego ewangelistę tekstów $\mathrm{z}$ Koh, jednak w miejscach, gdzie występują różnice w tłumaczeniu zostanie także przywołany tekst hebrajski Koh.

Odczytywanie tekstów NT, w których możliwe jest zauważenie użycia ksiąg ST, zazwyczaj dokonuje się w kluczu aluzji. Przez aluzję można rozumieć nawiązanie jednego tekstu do drugiego, przez co dany utwór posługuje się w mniejszym lub większym stopniu zawartością utworu źródłowego, przez co wyraża własną treść ${ }^{6}$. Może być przywołaniem tematu, bądź zespołu idei występujących $\mathrm{w}$ tekście chronologicznie wcześniejszym ${ }^{7}$. Badacze podają różne kryteria uznania danego tekstu za aluzję. G.K. Beale odnotowuje siedem założeń, które mogą świadczyć o tym, że dany tekst jest aluzją: 1) dostępność (zweryfikowanie czy tekst był dostępny dla pisarza); 2) stopień (ilość użytych słów lub fraz);3) powtarzalność (stwierdzenie, że pisarz więcej niż raz odniósł się do danego tekstu źródłowego); 4) spójność tematyczna (podobieństwo tematyczne między tekstem źródłowym a tekstem, który się do niego odnosi); 5) wiarygodność historyczna (pierwotni adresaci rozumieją intencje pisarza, który zastosował aluzję); 6) historia interpretacji (badacze tekstu biblijnego dostrzegli i odnotowali aluzję); 7) dopasowanie (zweryfikowanie czy aluzja spełnia pozostałe sześć kryteriów, czy wzmacnia przekaz retoryczny oraz czy wspomaga lepsze rozumienie tekstu) ${ }^{8}$. Sam G.K. Beale zauważa jednak, że czasem tekst nie spełnia tych kryteriów, a może zostać uznany za aluzję 9 . K. Górski zauważył, że tekst źródłowy i ten, który go wykorzystuje, mogą być do siebie w opozycji, a i tak w tekście nowszym będzie można mówić o aluzji ${ }^{10}$. Kryteria zaproponowane przez G.K. Bealego

5 Por. ibidem, s. 42-46.

6 Por. K. Górski, Aluzje literackie, s. 314-315.

7 Por. D. Kotecki, Aluzje do Księgi Sofoniasza, s. 109-110; por. G.T. Manning Jr, Echoes of a Prophet, s. 5.

8 Por. G.K. Beale, Handbook on the New Testament, s. 58-61. Inni badacze podają bardziej ogólne kryteria, jednak w większości ich założenia pokrywają się z kryteriami podanymi przez G.K. Bealego. Zob. K. Górski, Aluzje literackie, s. 315; zob. R.B. Hays, Echoes of Scripture, s. 29-32; zob. D. Kotecki, Aluzje do Księgi Sofoniasza, s. 111; zob. G.T. Manning Jr, Echoes of a Prophet, s. 9-14; zob. J.M. Pucci, The Full-Knowing Reader, s. 30-32.

9 Por. G.K. Beale, Handbook on the New Testament, s. 62.

10 Por. K. Górski, Aluzje literackie, s. 315. 
będą w dalszej części artykułu wyznacznikiem do określenia siły i rodzaju zależności między Łk a Koh.

Wśród aluzji można wymienić aluzje pewne, prawdopodobne, możliwe i echa ${ }^{11}$. Należy także odróżnić aluzję, która zawsze jest świadomym środkiem wyrazu, od wpływu, który może być nieświadomym wykorzystaniem tekstu chronologicznie wcześniejszego ${ }^{12}$. Można zatem stwierdzić, że relacja obu Testamentów to wiele cytatów, parafraz czy mniej lub bardziej widocznych aluzji ${ }^{13}$, jednak nie wyczerpuje to zagadnienia użycia ST przez NT i trzeba odnieść się do szeroko rozumianych relacji intertekstualnych ${ }^{14}$. Innego rodzaju nawiązaniem do ST mogą być np. typologie, czyli uznanie jakichś osób czy wydarzeń ze ST jako typy bądź zapowiedzi osób bądź wydarzeń $\mathrm{z} \mathrm{NT}^{15}$. Na gruncie przedstawionych powyżej założeń metodologicznych zostaną wskazane miejsca w Łk, w których można zaobserwować użycie Koh.

\section{Wykaz możliwych odniesień do Koh w Łk}

Wykaz możliwych odniesień sporządzono na podstawie studium tekstów Łk i Koh w oparciu o użycie takich samych słów w Koh LXX i Łk, następnie przenalizowano Łk pod względem tematycznych podobieństw z Koh zarówno w LXX, jak i BH. Kolejno został poddany krytycznej analizie komentarz G. K. Bealego i D. A. Carsona do użycia ST w NT ${ }^{16}$. Wyniki tego studium skonfrontowano z miejscami, w których krytyczne wydanie tekstu greckiego NT - Nestle-Aland Nowum Testamentum Graece (dalej: NTG) wskazuje zależność między Koh a Łk. Całościowe wyniki zaprezentowano w formie tabeli. Będą w niej przedstawione

11 Por. G.K. Beale, Handbook on the New Testament, s. 58; por. M. Karczewski, Reinterpretacja Księgi Rodzaju, s. 71-76; por. D. Kotecki, Aluzje do Księgi Sofoniasza, s. 110; por. J. Paulien, Criteria and Assessment, s. 113-129.

12 Por. K. Górski, Aluzje literackie, s. 314.

13 Por. J. Klinkowski, Zużytkowanie Starego Testamentu, s. 23-39.

14 Por. S. Jędrzejewski, Peszer w egzegezie nowotestamentalnej, s. 13.

15 Por. P. Podeszwa, Typologia Jonasz-Pawet, s. 35.

16 Zob. G. K. Beale, D. A. Carson, Commentary on the New Testament, s. 251-413. Autorzy omawiając możliwe użycia, często podają całe rozdziały Koh przez co trudno jest jasno określić wskazaną przez nich zależność. Niemniej przy tworzeniu tabeli możliwych odniesień uwzględniono także sugestie autorów. 
konkretne fragmenty z Łk, tekst źródłowy, czyli passus z Koh, a na końcu zostaną zaznaczone te miejsca, które jako połączone ze sobą wskazuje NTG.

\begin{tabular}{|c|c|c|c|}
\cline { 2 - 4 } \multicolumn{1}{c|}{} & Fragment & Źródło & NTG \\
\hline \multirow{4}{*}{} & $2,40.52$ & 1,16 & \\
\cline { 2 - 4 } & $8,5-8 \mathrm{a}$ & 11,6 & \\
\cline { 2 - 4 } & $8,25.35$ & $3,14 \mathrm{~b}$ & \\
\cline { 2 - 4 } & 11,42 & 7,18 & $\mathrm{X}$ \\
\cline { 2 - 4 } & 12,2 & 12,14 & $\mathrm{X}$ \\
\hline & $12,2-3$ & 10,20 & \\
\hline & 12,19 & 8,15 & $\mathrm{X}$ \\
\hline & 12,20 & 5,13 & \\
\hline & 12,20 & 6,$2 ; 9,12$ & \\
\hline & 12,25 & $3,14 \mathrm{a}$ & \\
\hline
\end{tabular}

W tekst trzeciej ewangelii - jak zauważa J. Klinkowski - wkomponowanych jest wiele typologii i modeli starotestamentalnych, które w różnych perykopach służą do rozwijania wątków teologicznych ${ }^{17}$. Analiza użycia Koh w Łk pozwoli stwierdzić czy tak samo jest w przypadku tych relacji tekstualnych. K. Mielcarek dodaje, że dzieło Łukasza ( $Ł k+D z)$ wyróżnia się na tle innych tekstów NT pięknem języka, specyfiką oraz, jak zostało wyżej powiedziane, szczególną relacją do tekstu LXX ${ }^{18}$. Z tego powodu właśnie ten tekst NT wydaje się być odpowiednim, aby ukazać zależności pomiędzy nim a Koh.

\section{Analiza wybranych fragmentów}

W Łk znajduje się osiem fragmentów, w których można widzieć odniesienia do Koh $(2,40.52 ; 8,5-8 \mathrm{a} ; 8,25.35 ; 11,42 ; 12,2-3 ; 12,19 ; 12,20 ; 12,25)$. NTG wskazuje na trzy miejsca ( $Ł k 11,42 ; 12,2 ; 12,19)$, które pozostają w relacji intertekstualnej z trzema tekstami z Koh $(7,18 ; 12,14 ; 8,15)$. Analiza tekstów z Koh w Łk ma odpowiedzieć przede wszystkim na pytanie czy można w trzeciej ewangelii

17 Por. J. Klinkowski, Zużytkowanie Starego Testamentu, s. 242-243.

18 Por. K. Mielcarek, Język Septuaginty, s. 33. 40-46. 
rzeczywiście odnaleźć miejsca, w których użyta jest Księga Koheleta, a jeśli tak, to na czym polega ta zależność. Zależność ta będzie określana na postawie kryteriów przedstawionych w założeniach metodologicznych zaprezentowanych we wcześniejszej części tego artykułu. Warto zaznaczyć, że trzy z tych kryteriów, a więc dostępność, powtarzalność i wiarygodność historyczna są spełnione we wszystkich omawianych poniżej fragmentach.

\section{1. $七 k 2,40.52$}

\begin{tabular}{|c|c|}
\hline 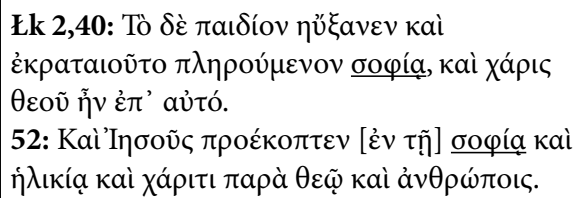 & 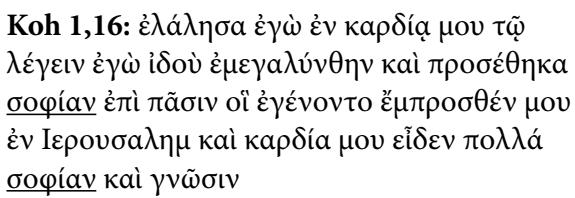 \\
\hline $\begin{array}{l}\text { Łk 2,40: Dziecię zaś wzrastało i rosło w siłę, } \\
\text { zostając napełnianym mądrością, i łaska Boga } \\
\text { była na Nim. } \\
\text { 52: I Jezus postępował w mądrości i latach } \\
\text { i łasce u Boga i ludzi. }\end{array}$ & $\begin{array}{l}\text { Koh 1,16: Powiedziałem ja w sercu moim, } \\
\text { mówiąc: uczyniłem dużo i dodałem mądrości } \\
\text { nad wszystkich, którzy stali się przede mną } \\
\text { w Jerozolimie i serce moje widziało wiele } \\
\text { mądrości i wiedzy. }\end{array}$ \\
\hline
\end{tabular}

W tych tekstach, w warstwie semantycznej zachodzi podobieństwo w użyciu tylko jednego słowa, którym jest „mądrość” (бọía). Warto jednak zauważyć, że jest to słowo stanowiące centrum wypowiedzi Koheleta i ważną część wskazanych fragmentów Łk. Biorąc pod uwagę kryteria, które przytoczono wcześniej, należy zauważyć, że pomimo, iż stopień zależności, czyli ilość powtarzanych słów i fraz jest niemalże zerowy, to jednak występuje spójność tematyczna. Mimo, że wcześniej badacze nie wykazywali podobieństw między Koh 1,16 a Łk 2,40.52, można zobaczyć pewną zależność pomiędzy tymi passusami. W tekście LXX i masoreckim ${ }^{19}$ (dalej: TM) nie ma większych różnic.

Należy zwrócić uwagę, że relacja intertekstualna może zajść nie tylko w warstwie semantycznej, ale dodatkowo, czyny i wydarzenia związane z konkretną osobą mogą być ilustracją słów mędrca, a jednocześnie wskazywać na użycie Koh przez autora trzeciej ewangelii. Wydaje się, że tak właśnie jest w Łk. Jezus Mesjasz, najdoskonalszy władca związany z Jerozolimą, dodaje nową jakość do

19 Tekst masorecki powstał w IX/X w. po Chr. Masoreci dodali samogłoski do tekstu Biblii Hebrajskiej. Zob. M. Rosik, I. Rapaport, Wprowadzenie do literatury, s. 13. 
słów Koheleta. Przed Koheletem, który w tym wersecie identyfikuje się z Salomonem ${ }^{20}$, nie było w Jerozolimie nikogo obdarzonego taką wiedzą i mądrością. Dopiero w Jezusie Chrystusie mądrość i wiedza stają się najpełniejsze ${ }^{21}$, ponieważ jako Syn Boży widzi i wie rzeczy, które są niedostępne nawet dla najbardziej światłego z królów Izraela. Należy zatem stwierdzić, że Łk 2,40.52 używa Koh 1,16 dodającą nową jakość do tekstu mądrościowego. Można postawić twierdzenie, że Kohelet określający się jako zdobywający mądrość władca Izraela jest typem Jezusa, najdoskonalszego i posiadającego największą mądrość Pana.

\section{2. $七 k 8,5-8 a$}

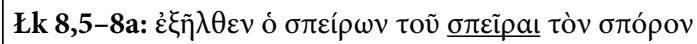

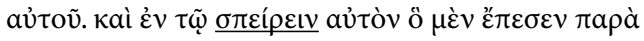

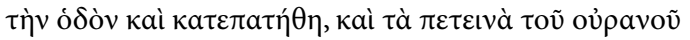

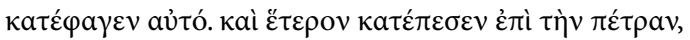

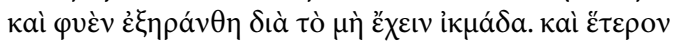

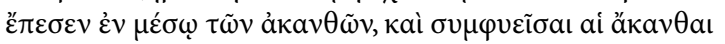

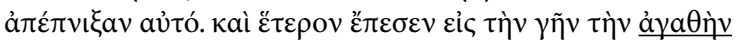

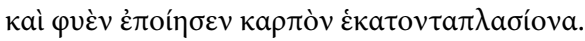

Łk 8,5-8a: Siejący wyszedł siać ziarno jego. I gdy siał, jedno upadło na drogę i zostało podeptane, i ptaki powietrzne zjadły je. I inne upadło na skałę, i gdy wzeszło uschło, przez to, że nie ma wilgoci. I inne upadło pomiędzy ciernie, a ciernie wzeszły razem $z$ nim i zagłuszy je. I inne upadło do dobrej ziemi, i gdy urosło wydało stokrotne owoce.

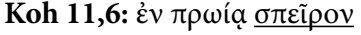

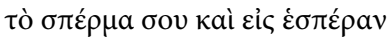

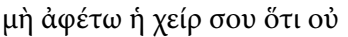

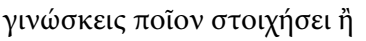

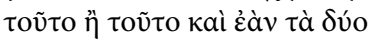

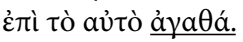

Koh 11,6: Rano siej nasienie swoje i do wieczora nie odpuszczaj swojej ręce, ponieważ nie wiesz jaki rodzaj to jedno czy drugie, czy dwa są dobre.

W Łk 8,5-8a i Koh 11,6 występuje ten sam czasownik na oznaczenie czynności siania ( $\sigma \pi \varepsilon i ́ \rho \omega)$. W Koh zostaje nazwana możliwa jakość ziarna jako dobra, a w Łk ziemia poprzez ten sam przymiotnik (ảjäóc), właściwie uzgodniony z rodzajem rzeczownika, który określa. Stopień występowania aluzji nie jest wysoki, jednak zbieżny jest czasownik wyrażający główną czynność w obu fragmentach. Występuje także spójność tematyczna pomiędzy Koh 11,6 a Łk 8,5-8a dotycząca siewcy, który wykonuje czynność siania. W analizowanych komen-

20 Por. D.A. Garrett, Proverbs, Ecclesiastes, s. 290; por. R.E. Murphy, Ecclesiastes, s. 14; por. G.S. Ogden, L.Zogbo, A Handbook on Ecclesiastes, s. 46-47; por. J. Winter, Opening up Ecclesiastes, s. $28-29$.

21 Por. W. Hendriksen, Exposition of the Gospel, s. 179-180.186-187. 
tarzach do Koh i Łk nie zostały wskazane powiązania pomiędzy tymi tekstami, jednak ze względu na pewien, choć niewielki stopień oraz spójność tematyczną można stwierdzić występowanie związku pomiędzy tymi passusami i określić Łk 8,5-8a jako echo Koh 11,6. Ten tekst mądrościowy zarówno w LXX, jak i TM brzmi właściwie jednakowo.

Kohelet zwraca uwagę na wytrwałość siewcy i nieznaną jakość ziarna, bądź pory zasiewu, prawdopodobnie sugerując, że zależy to od Boga ${ }^{22}$. Świadczyć o tym mogą także imperatywy zachęcające do siewu użyte w aoryście. Czas ten wskazuje, że żeby zrealizować zalecaną czynność potrzebne jest wsparcie od Boga ${ }^{23}$. Ewangelista natomiast skupia się na miejscu, na które upada ziarno i na tym, jaki spotyka je los, który również jest uzależniony od woli Stwórcy, o czym dowodzi użycie czasowników w stronie biernej (passivum divinum). Zarówno w Koh, jak i w Łk odniesienie do zasiewu ziarna jest naturalnym obrazem dla słuchaczy, którzy w dużej części pochodzili z terenów rolniczych ${ }^{24}$. Kohelet w swoim tekście nawiązuje do tego, że nawet uprawa roli jest zależna od Boga. Łukasz będąc pod wpływem tych słów prezentuje je w przypowieści, która nadaje sianemu ziarnu nowe znaczenie. Po raz kolejny można zaobserwować, że ewangelista wykorzystuje fragment księgi mądrościowej, aby poprzez słowa i czyny Jezusa nadać mu nową jakość.

\section{3. $七 k 8,25.35$}

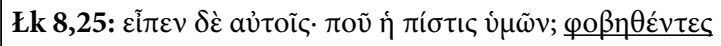

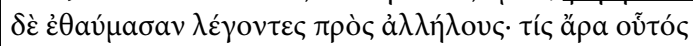

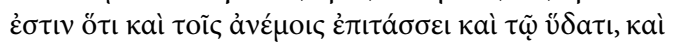

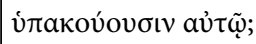

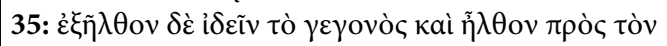

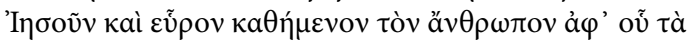

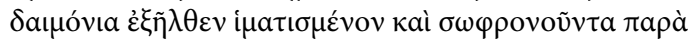

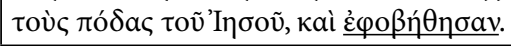

22 Por. D.C. Fredericks, Life's Storms, s. 98-99; por. R.E. Murphy, Ecclesiastes, s. 109; por. C. Whitwell, The Variation of Nature, s. 85-86.

23 Zob. K. Olszewska, Imperatywy jako narzędzia formacji, s. 67-76 [manuskrypt w archiwum autora].

24 Por. W. Hendriksen, Exposition of the Gospel, s. 422-423; por. G.S. Ogden, L. Zogbo, A Handbook on Ecclesiastes, s. 401-404. 
Łk 8,25: I powiedział im: Gdzie jest wasza wiara? [Oni] zaś zostali przestraszeni i pełni podziwu mówili jeden do drugiego: Kim więc On jest, że wiatrom rozkazuje i wodzie, i słuchają Go.

35: Wyszli zaś zobaczyć co się stało i przyszli do Jezusa, i znaleźli człowieka, z którego wyszedł demon, będącego ubranym, siedzącego u stóp Jezusa, i byli przestraszeni.

Koh 3,14b: i Bóg tak działa, żeby byli przestraszeni z powodu Jego obecności.

Strach w Łk 8,25.35 oraz Koh 3,14b jest określony tym samym czasownikiem $(\varphi \circ \beta \varepsilon ́ \omega)$. W warstwie semantycznej to jedyne podobieństwo jakie zachodzi, zatem stopień aluzyjność pod tym względem jest niemalże niewidoczny. Biorąc jednak pod uwagę zależność kontekstualną i spójność tematyczną, można stwierdzić, że trzeci ewangelista korzystając $\mathrm{z}$ tradycji mądrościowej doprecyzowuje i rozwija syntetycznie przedstawione przez Koheleta zdanie. Wcześniejsze badania nie pokazywały zależności pomiędzy tymi fragmentami. Jednak można stwierdzić, że Łk 8,25.35 w niewielkim stopniu pozostaje pod wpływem Koh 3,14b i jest jego echem. Tekst Koh 3,14b w LXX i TM jest ze sobą zgodny.

Spektakularne cuda Jezusa - takie jak uciszenie burzy oraz wypędzenie złego ducha - spotykały się ze strachem tych, którzy je widzieli. Zarówno w Koh, jak i Łk bojaźń człowieka jest dziełem Boga (passivum divinum). Komentatorzy Koh uważają, że mędrzec kładzie nacisk na strach przed Bogiem, który jest wynikiem Jego tajemniczego działania. Strach ten może być rozumiany pozytywnie - jako przejaw bojaźni przed Bogiem lub negatywnie - jako chęć ucieczki przed Nim ${ }^{25}$. Podobnie w przypadku Łk badacze nie są przekonani jakiego rodzaju strach towarzyszył tym, którzy widzieli cuda Jezusa ${ }^{26}$. Mędrzec nie konkretyzuje dzieł Boga. Ewangelista natomiast podaje konkretne czyny Jezusa, które spotykają się z pełną lęku reakcją ludzi. Nie jest do końca pewne, jak zostało wyżej zauważone, czy ujrzenie cudów prowadziło do bojaźni i wiary w Boga, czy do ucieczki przed Nim. Po raz kolejny zatem Łukasz odnosi się do słów Koheleta prezentując w nowy sposób ich przesłanie i aplikując je do osoby Jezusa Chrystusa.

25 Por. T. Longman III, The 'Fear of God', s. 15; por. R. E. Murphy, Ecclesiastes, s. 35; por. G.S. Ogden, L. Zogbo, A Handbook on Ecclesiastes, s. 106.

26 Por. W. Hendriksen, Exposition of the Gospel, s. 442.448; por. I.H. Marshall, The Gospel of Luke, s. 334-335. 


\section{4. Łk 11,42}

\begin{tabular}{|c|c|}
\hline 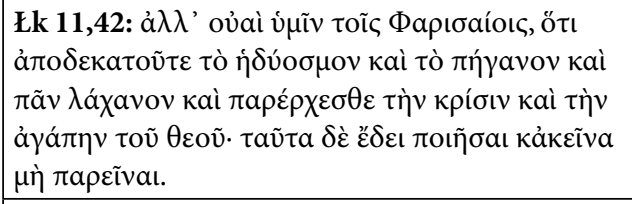 & 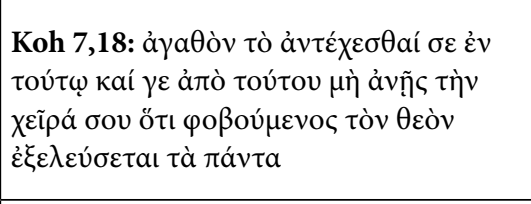 \\
\hline $\begin{array}{l}\text { Lk 11,42: Ale biada wam faryzeuszom, ponieważ } \\
\text { dajecie dziesięcinę mięty i ruty, i każdej rośliny } \\
\text { jadalnej, i omijacie sprawiedliwość, i miłość } \\
\text { Boga. To zaś było konieczne czynić, i tamtego nie } \\
\text { zaniedbać. }\end{array}$ & $\begin{array}{l}\text { Koh 7,18: Dobrze, że trzymasz się } \\
\text { jednego i z drugiego nie zwalniasz ręki } \\
\text { swojej, ponieważ bojący się Boga uniknie } \\
\text { tego wszystkiego. }\end{array}$ \\
\hline
\end{tabular}

Jak zostało zauważone w NTG, Łk 11,42 jest nawiązaniem do Koh 7,18. Oba teksty łączy silne podobieństwo tematyczne, lecz nie zachodzi związek w warstwie semantycznej. W Łk nie ma ani jednego słowa zawartego w Koh 7,18 LXX. Należy zatem określić stopień aluzyjności jako zerowy. Jednak spójność tematyczna jest bardzo ścisła. Także historia interpretacji (wymieniony chociażby wcześniej NTG) wskazują, że zachodzi relacja intertekstualna między Koh 7,18 a Łk 11,42. Można zatem stwierdzić, że Łk 11,42 jest co najmniej echem Koh 7,18. Tekst tego fragmentu w LXX i TM ma jednakowe brzmienie.

Według R.E. Murphy’ego, zarówno praktykowanie cnót, jak i wad ma swoje ograniczenia. Drogą do pożądanego sukcesu jest natomiast kierowanie się lękiem przed Bogiem. To dzięki niemu można odnaleźć życiową równowagę, która pozwoli wieść satysfakcjonujące życie ${ }^{27}$. Słowa zawarte w Koh 7,18 są jakby przeciwieństwem przestrogi z Łk 11,42. Mędrzec chwali tych, którzy praktykują zasadę złotego środka. Ewangelista natomiast upomina faryzeuszów, którzy przywiązują wielką wagę do składania dziesięciny z najdrobniejszych dóbr, a nie praktykują tego, co stanowi istotę ich religii, a więc sprawiedliwości i miłości. Także i Łukasz jest zwolennikiem zasady złotego środka, o czym świadczy dopowiedzenie, że zarówno ofiary, jak i dobre czyny wobec bliźnich powinny być wykonywane z należytą rozwagą ${ }^{28}$.

27 Por. R.E. Murphy, Ecclesiastes, s. 70; por. D.A. Garrett, Proverbs, Ecclesiastes, s. 323; por. G.S. Ogden, L. Zogbo, A Handbook on Ecclesiastes, s. 252-254; zob. J.H. Choi, The Doctrine of the Golden, s. 358-374; zob. T. Longman III, The 'Fear of God', s. 13-21; zob. W.R. Steel, Enjoying the Righteousness, s. 229.

28 Por. W. Hendriksen, Exposition of the Gospel, s. 638-639. 


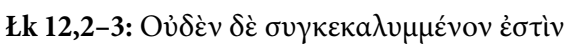
ö oủk ảं

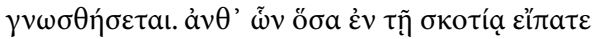

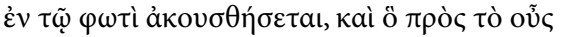

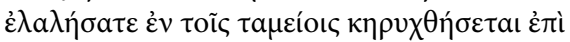
$\tau \tilde{\omega} v \delta \omega \mu \alpha \dot{\tau} \tau \omega v$.

Lk 12,2-3: Nic nie zostało i nie jest ukryte, co nie będzie ujawnione, i schowane, co nie będzie wiadome. Zamiast tego, co tak wiele w ciemności powiedzieliście, $\mathrm{w}$ świetle będzie usłyszane i co do ucha powiedzieliście w składziku, będzie głoszone na dachach.

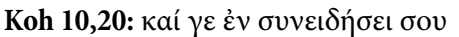

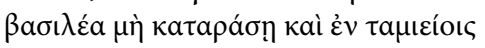

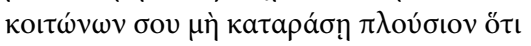

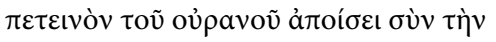

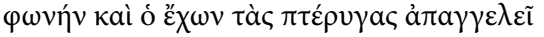

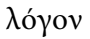

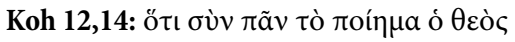

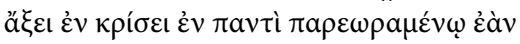

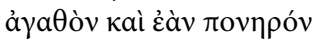

Koh 10,20: I nawet w sumieniu swoim króla nie przekląłeś, i w wewnętrznych częściach sypialni nie przekląłeś bogatego, ponieważ ptaki powietrzne zaniosą głos, i mający skrzydła obwieszczą słowo.

Koh 12,14: Bowiem ze wszystkich dzieł Bóg będzie prowadził na sąd, wszystkich niezwracających uwagi, czy dobro, czy zło.

Dwaj badacze G.K. Beale i D.A. Carson w swoim komentarzu do użycia ST w NT zauważają zależność pomiędzy Łk 12,2 i Koh 10,20. Sugerują, że Łk 12,2 jest echem Koh 10,20 ${ }^{29}$. W. Hendriksen, podobnie jak NTG uważa, że Łk 12,2 to echo Koh 12,14 ${ }^{30}$. Między Łk 12,2-3 a Koh 10,20 i 12,14 nie ma podobieństw w warstwie semantycznej. Oznacza to, według kryteriów podanych przez G. K. Bealego, że stopień aluzyjności między tymi fragmentami nie zachodzi. Jeśli zostanie przyjęte, że Łk 12,2 to echo wymienionych wyżej passusów mądrościowych, to zależność ta zachodzi na podstawie spójności tematycznej a potwierdza ją historia interpretacji. Tekst LXX i MT Koh 10,20 i 12,14 można przetłumaczyć w podobny sposób.

Zdaniem R.E. Murphy'ego, w Koh 10,20 jest ukryta kolejna przestroga przed sprzeniewierzaniem się władzy królewskiej ${ }^{31}$. Koh 12,14 pokazuje, że Bóg nie ma względu na osoby. Każdy, niezależnie od tego, czy jest dobry czy zły, zostanie rozliczony ze swoich czynów ${ }^{32}$. To, co mędrzec opisuje według ziemskich stan-

\footnotetext{
29 Por. G.K. Beale, D.A. Carson, Commentary on the New Testament, s. 325.

30 Por. W. Hendriksen, Exposition of the Gospel, s. 651.

31 Por. R.E. Murphy, Ecclesiastes, s. 106; zob. E.W.F. Goh, Political Wisdom, s. 30-47.

32 Por. G.S. Ogden, L. Zogbo, A Handbook on Ecclesiastes, s. 444.
} 
dardów w Koh 10,20, w Łk przedstawione jest w kluczu Bożych atrybutów. Koh 10,20 to przestroga dotycząca uważności w głoszeniu sądów przeciwko władzy ziemskiej, w Łk pokazane jest natomiast, że to Bóg wie wszystko, co nosi w swoim sercu człowiek. Podobna konkluzja towarzyszy Eklezjastesowi w 12,14. Można zatem powiedzieć, że ewangelista pokazuje jakościowo nowe rozumienie słów zawartych w Koh 10,20, akcentując Bożą wszechwiedzę i nieuniknioność sądu podobnie jak w Koh 12,14.

\section{6. $Ł k 12,19$}

\begin{tabular}{|c|c|}
\hline 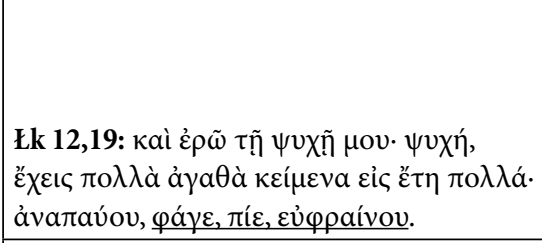 & 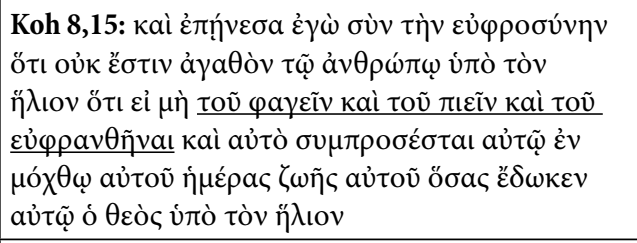 \\
\hline $\begin{array}{l}\text { Łk 12,19: I powiem w duszy swojej: duszo, } \\
\text { masz wielkie dobra złożone na długie } \\
\text { lata; odpocznij, jedz, pij i raduj się. }\end{array}$ & $\begin{array}{l}\text { Koh 8,15: I sławiłem radość, ponieważ nic nie jest } \\
\text { dobre dla człowieka pod słońcem, jeśli nie to, że je } \\
\text { i pije, i raduje się, i będzie to z nim w jego trudzie } \\
\text { za dni jego życia, które tak licznie dał mu Bóg } \\
\text { pod słońcem. }\end{array}$ \\
\hline
\end{tabular}

NTG wskazuje, że Łk 12,19 jest aluzją do Koh 8,15. Można zauważyć podobieństwo we frazie związanej z jedzeniem, piciem i radowaniem się (Łk: $\varphi a ́ \gamma \varepsilon$,

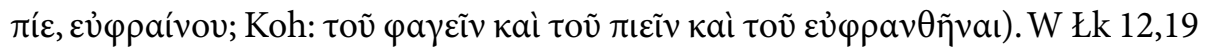
jest to fraza złożona z imperatywów zarówno czasu teraźniejszego, jak i aorystu. Koh 8,15 to konstrukcja w języku greckim zestawiająca rodzajnik w dopełniaczu z bezokolicznikiem, aby zwrócić uwagę na cel, skutek, albo wyjaśnienie czegoś. W tym wypadku stopień aluzyjności jest dosyć wysoki. Można zatem stwierdzić, że Łk 12,19 jest prawdopodobną aluzją do Koh 8,15, co potwierdza także spójność tematyczna tych tekstów oraz historia interpretacji. Koh 8,15 zarówno w LXX, jak i TM brzmi jednakowo.

Powodem radości w Koh 8,15 nie jest fakt zgromadzenia mnogich dóbr, ale to, że Bóg dał człowiekowi wiele lat życia, w czasie których może korzystać z tego wszystkiego, co podarował mu Stwórca ${ }^{33}$. W łukaszowej przypowieści bogacz

33 Por. R.E. Murphy, Ecclesiastes, s. 86; por. G.S. Ogden, L. Zogbo, A Handbook on Ecclesiastes, s. 306-308. 
nie jest zainteresowany odniesieniem do Boga, lecz cieszy się tym, co materialne, w czym dostrzega zapewnienie długiego życia ${ }^{34}$. Można także zauważyć, że cała przypowieść o bogaczu jest ilustracją tego mądrościowego wersetu.

\section{7. $Ł k 12,20$}

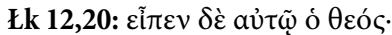

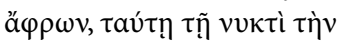

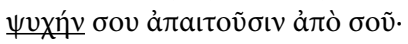

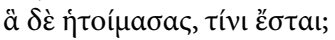

Lk 12,20: Powiedział zaś mu Bóg: Głupcze, taj nocy zażądaj duszy twojej od ciebie, więc komu przygotowałeś to, co jest?
Koh 5,13: кaì ảं

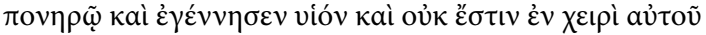
oủ $\delta \dot{v} v$

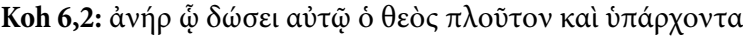

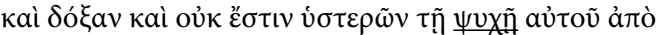

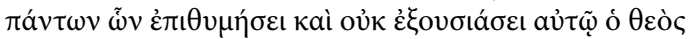

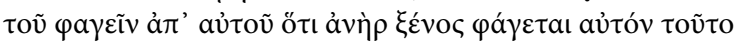

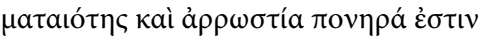

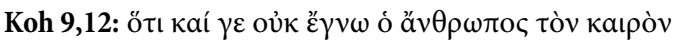

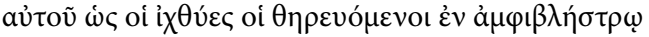

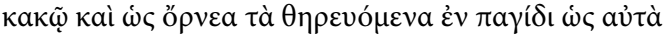

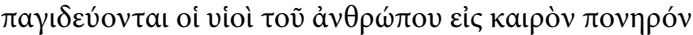

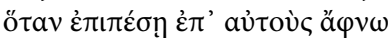

Koh 5,13: I przepadnie bogactwo z powodu zatracającego zła i zrodził syna, i nie ma nic w jego ręce.

Koh 6,2: Dusza męża, któremu będzie dawał Bóg bogactwo i życie, i chwałę, nie potrzebuje tego wszystkiego, czego będzie pragnął, i nie pozwoli mu Bóg jeść z jego, ponieważ mąż obcy będzie jadł z jego, wszystko jest marnością, i złą słabością.

Koh 9,12: Ponieważ i nawet nie zna człowiek czasu swojego jak ryby, które są łapane w sieć złą, i jak ptaki są łapane w pułapkę, jak one są usidlone, tak synowie ludzcy do czasu złego, który kiedykolwiek spadł na nich nagle.

W Koh 5,13 i Łk 12,20 zachodzi spójność tematyczna obu fragmentów. Zarówno Kohelet, jak i Łukasz przestrzegają przed posiadaniem bogactwa jedynie z powodu chęci samego posiadania. Stopień aluzyjności tych fragmentów jest jednak zerowy, ponieważ nie zachodzi żadne podobieństwo w warstwie semantycznej. Historia interpretacji również nie odnotowuje zależności pomiędzy Koh 5,13 a Łk 12,20. Jednak kryterium spójności tematycznej w tym przypadku wy-

34 Por. F.S. Spencer, To Fear and Not to Fear, s. 242. 
daje się na tyle przekonujące, że można stwierdzić, iż Łk 12,20 jest echem Koh 5,13. To, co w Koh zapisane jest w mądrościowej przestrodze, w Łk zaprezentowane zostaje, jak zostało wyżej nadmienione, jako przypowieść będąca ilustracją tych słów. Według G.S. Ogdena i L. Zogbo zdanie zawarte w Koh 5,13 sugeruje, że nie chodzi o podkreślenie utraty bogactwa, a pokazanie bezwartościowości pracy w chwili śmierci. Ich zdaniem Kohelet doprowadza do kluczowego pytania o trwałą korzyść ${ }^{35}$. W. Hendriksen, interpretując Łk 12,20, również konstatuje, że największą przewiną bogacza było nie tyle posiadanie, ile chęć kontroli nawet nad końcem życia ${ }^{36}$. Także w tym przypadku wydaje się, że Jezusowa przypowieść jest pogłębioną ilustracją słów Koheleta.

Po raz pierwszy w omawianych $\mathrm{w}$ artykule tekstach, wersja grecka Koh 6,2 różni się w warstwie semantycznej od wersji hebrajskiej, która brzmi:

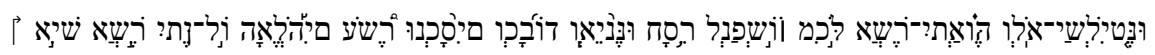

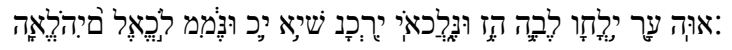

i można ją przetłumaczyć: "Jakiemuś człowiekowi dał Bóg majątek i bogactwo, i chwałe, i niczego nie zabraknie jego duszy ze wszystkiego, czego pragnie, ale nie daje mu Bóg możliwości, żeby jeść, lecz człowiek obcy to je, to wszystko marność i złe cierpienie". Różnicę pomiędzy Koh 6,2 LXX a TM szczególnie widać we frazie:

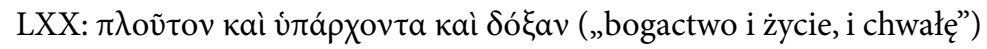

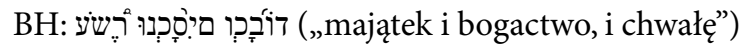

Tekst grecki nawiązuje do dania przez Boga całego ludzkiego życia, co zostało

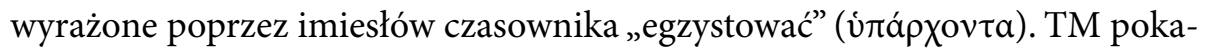
zuje natomiast, że Bóg jest sprawcą dobrostanu materialnego w życiu człowieka. Wydaje się zatem, że pomimo, iż trzeci ewangelista odnosi się do bogactwa w całej przypowieści, której Łk 12,20 jest częścią, to przez stwierdzenie, że Bóg może zażądać od bogacza całego życia widać większe nawiązanie do Koh 6,2 LXX.

35 Por. G.S. Ogden, L. Zogbo, A Handbook on Ecclesiastes, s. 177. Podobnie: zob. D.A. Garrett, Proverbs, Ecclesiastes, s. 314; zob. M.S. Rindge, Morality and Enjoyment, s. 265-280. J. Winter uważa natomiast, że nadmierne bogactwo prowadzi do postradania zmysłów: zob. idem, Opening up Ecclesiastes, s. 79-80.

36 Por. W. Hendriksen, Exposition of the Gospel, s. 664. Podobnie: zob. I.H. Marshall, The Gospel of Luke, s. 524; zob. R.H. Stein, Luke, s. 352. 
Warto także zwrócić uwagę, że zarówno w Koh 6,2 LXX (TM również), jak i Łk 12,20 konstytutywnym elementem człowieka, na który powołują się oba teksty jest dusza ( $\psi v \chi \eta ́)$. Można zatem stwierdzić, że stopień aluzyjności między tymi tekstami jest nieznaczny, jednak uwzględniając spójność tematyczną w Łk 12,20 należy widzieć echo Koh 6,2.

W Koh 9,12 stopień aluzyjności jest zerowy. Widoczna jest natomiast spójność tematyczna obu fragmentów. Koh 9,12 podkreśla, że nie jest znany czas, w którym nieszczęście spadnie na człowieka. Śmierć jest najbardziej nieprzewidywalnym zdarzeniem w jego życiu ${ }^{37}$. W naturze ludzkiej zapisana jest chęć do życia i lęk przed jego końcem. W Koh 9,12, podobnie jak w 5,13 i Łk 12,20 tylko Bóg zna kres życia człowieka. Po raz kolejny zostaje podkreślony także fakt, że śmierć dla człowieka wiąże się z nieprzewidywalnym cierpieniem i trudno jest mu zapanować nad lękiem przed nią. Można zatem powiedzieć, że w Łk 12,20 widać wpływ wszystkich trzech wskazanych powyżej tekstów z Koh, pomimo, że nie przemawia za tym historia interpretacji. Jednak należy stwierdzić, że Łk 12,20 to echo Koh 5,13; 6,2; 9,12.

\section{8. Łk 12,25}

\begin{tabular}{|c|c|}
\hline 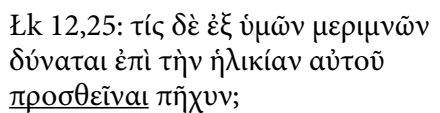 & 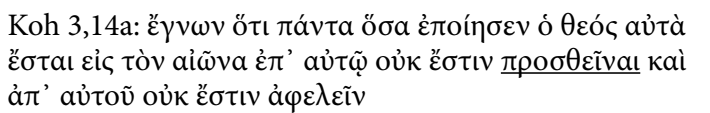 \\
\hline $\begin{array}{l}\text { Łk 12,25: Kto z was, będąc } \\
\text { przejętym, do wieku swojego jest } \\
\text { w stanie dodać łokieć? }\end{array}$ & $\begin{array}{l}\text { Koh 3,14a: Poznałem, że wszystko, co wielkiego zrobił } \\
\text { Bóg, na wieki jest, do tego nie jest dodane, ani z tego nie } \\
\text { jest zabrane. }\end{array}$ \\
\hline
\end{tabular}

Na określenie dodania czegoś, zarówno w Łk, jak i Koh, użyty jest ten sam bezokolicznik w aoryście ( $\pi \rho 0 \sigma \theta \varepsilon \tilde{v} v a$ ). W warstwie słownej jest to jedyne podobieństwo między tymi tekstami. Zgodnie z kryteriami zaproponowanymi przez G. K. Bealego stopień aluzyjności należy określić jako niewielki. Pomiędzy Koh 3,14a a Łk 12,25 zachodzi jednak spójność tematyczna. Z tego powodu, mimo że dotychczasowa historia interpretacji tego nie potwierdza, w Łk 12,25 można widzieć echo Koh 3,14a. Koh 3,14a zarówno w LXX, jak i TM brzmią niemal identycznie.

37 Por. D.A. Garrett, Proverbs, Ecclesiastes, s. 332; por. G.S. Ogden, L. Zogbo, A Handbook on Ecclesiastes, s. 341; por. J. Winter, Opening up Ecclesiastes, s. 122. 
W Koh 3,14a w wielkich dziełach, których dokonał Bóg, można widzieć porządek stworzenia ${ }^{38}$ i Boże istnienie w czasie, do którego już nic nie można dodać, ani odjąć. W Łk 12,25 podkreślone jest, że człowiek nie ma możliwości sam przedłużyć swojego życia. R.H. Stein uważa, że człowiek, który martwi się o swoje życie, nie może nic z nim zrobić, w przeciwieństwie do człowieka wierzącego, który dzięki Bożej interwencji może żyć dłużej ${ }^{39}$. Patrząc na oba teksty, należy uznać, że Bóg niezmienny w swojej naturze jest w stanie sprawić dla człowieka wierzącego to, czego człowiek zbytnio przejęty swoim życiem sam zrobić nie może - a więc zmienić godziny swojej śmierci.

\section{Podsumowanie}

Podsumowując, należy uznać, że użycie Księgi Koheleta w Łk nie jest ewidentne, ponieważ w trzeciej ewangelii nie znajdują się żadne cytaty z tej księgi mądrościowej. Posługując się jednak tak szerokim pojęciem jak użycie Koh w Łk, w którym mieszczą się nie tylko aluzje do tekstu źródłowego, ale także pewne ilustracje, polemiki, typologie czy podjęcie i rozwinięcie podobnych tematów, należy zauważyć, że wskazane powyżej w tabeli teksty Łk są w intertekstualnej relacji z Koh. Najczęściej w passusach trzeciej ewangelii można widzieć echo słów zapisanych przez Eklezjastesa. Nie jest to jednak jedyny rodzaj związku zachodzący pomiędzy tymi tekstami. W Koh 1,16 bohater przedstawiony jako Salomon może być typem Jezusa pokazanego w Łk 2,40.52. W Łk 12,19 można widzieć natomiast prawdopodobną aluzję do Koh 8,15.

Patrząc na poddane analizie fragmenty, można stwierdzić, że ewangelista dokonał reinterpretacji, czyli odczytania na nowo już wcześniej poddanego interpretacji tekstu ${ }^{40}$. Użycie typologii, aluzji i ech w zaprezentowanych powyżej tekstach wpisuje się w reinterpretację teologiczną, a zwłaszcza chrystologiczną. Trzeci ewangelista zaktualizował słowa mędrca, wpisując je w historię Jezusa Chrystusa, lub nawet przypisując Jezusowi wykorzystanie Koh poprzez nauczanie w przypowieściach.

38 Por. G.S. Ogden, L. Zogbo, A Handbook on Ecclesiastes, s. 105.

39 Por. R.H. Stein, Luke, s. 355.

40 Por. Reinteroretacja, SJP, [dostęp online 14.11.2021: https://sjp.pwn.pl/sjp/reinterpretacja; 2514633]. 


\section{Bibliografia}

\section{Teksty źródłowe}

Biblia Hebraica Stuttgartensia, red. K. Elliger, W. Rudulph, Carol Stream, IL $2006^{5}$.

Novum Testamentum Graece, red. B.K., Aland, J. Karavidopoulos, C.M. Martini, B.M. Metzger, Stuttgart $2012^{28}$.

\section{Literatura przedmiotu}

Beale G.K., Carson D.A., Commentary on the New Testament Use of the Old Testament, Grand Rapids, MI 2007.

Beale G.K., Handbook on the New Testament Use of the Old Testament: Exegesis and Interpretation, Grand Rapids, MI 2012.

Choi J.H., The Doctrine of the Golden Mean in Qoh 7:15-18: a Universal Human Pursuit, Biblica 83 (2002) 3, s. 358-374.

Fredericks D.C., Life's Storms and Structural Unity in Qoheleth 11.1-12.8, Journal for the Study of the Old Testament 52 (1991), s. 95-114.

Garrett D.A., Proverbs, Ecclesiastes, Song of Songs, The New American Commentary, v. 14, Nashville 1993.

Goh E.W.F., Political Wisdom in the Book of Ecclesiastes, Asia Journal of Theology 30 (2016) 1, s. 30-47.

Górski K., Aluzja literacka (Istota zjawiska i jego typologia), w: Problemy teorii literatury. Seria

I, red. H. Markiewicz, Wrocław-Warszawa-Kraków 1987, s. 314-338.

Hays R.B., Echoes of Scripture in the Letters of Paul, New Haven, CT 1993.

Hendriksen W., Exposition of the Gospel According to Luke, New Testament Commentary, Grand Rapids, MI 1978.

Jędrzejewski S., Peszer w egzegezie nowotestamentalnej, Seminare 39 (2018) 3, s. 11-22.

Karczewski M., Reinterpretacja Księgi Rodzaju w Apokalipsie św. Jana, Biblioteka Wydziału Teologii Uniwersytetu Warmińsko-Mazurskiego w Olsztynie, nr 55, Olsztyn 2010.

Klinkowski J., Zużytkowanie Starego Testamentu w Nowym, Legnica 2000.

Kotecki D., Aluzje do Ksiegi Sofoniasza w Nowym Testamencie?, Collectanea Theologica 87 (2017) 4, s. 107-124.

Longman III T., The 'Fear of God' in the Book of Ecclesiastes, Bulletin for Biblical Research 25 (2015) 1, s. 13-21.

Manning Jr G. T., Echoes of a Prophet. The Use of Ezekiel in the Gospel of John and in Literature of the Second Temple Period, JSNT Supplement Series 270, London-New York 2004. 
Marshall I.H., The Gospel of Luke, The New International Greek Testament Commentary, Grand Rapids, MI 1978.

Mielcarek K., Język Septuaginty i jego wpływ na autora trzeciej Ewangelii, Roczniki Teologiczne XLIX (2002) 1, s. 33-47.

Murphy R.E., Ecclesiastes, Word Biblical Commentary 23A, Nashville 1992.

Nawrot J., Aluzje literackie w teologicznej ocenie działań arcykapłana Szymona w 1 Mch 14,5, Biblical Annals 11 (2021) 1, s. 5-23.

Nycz R., Intertekstualność i jej zakresy: teksty, gatunki, światy, Pamiętnik Literacki: czasopismo kwartalne poświęcone historii i krytyce literatury polskiej 81 (1990), s. 95-116.

Ogden G.S., Zogbo L., A Handbook on Ecclesiastes, United Bible Societies Handbook Series, New York 1997.

Olszewska K., Imperatywy jako narzędzia formacji chrześcijan w Apokalipsie św. Jana, Toruń 2021 [manuskrypt w archiwum autora].

Paulien J., Criteria and Assessment of Allusions to the Old Testament in the Book of Revelations, w: Studies in the Book of Revelation, red. S. Moyise, Edinburgh 2001, s. 113-129.

Podeszwa P. Typologia Jonasz-Paweł w narracji o podróży morskiej do Rzymu (Dz 27,13-28,16), Teologia i Człowiek 20 (2012) 2, s. 27-45.

Pucci J.M., The Full-Knowing Reader. Allusion and the Power of the Reader in the Western Literary Tradition, New Haven, CT 1998.

Rafiński G., Odniesienia do Starego Testamentu w Listach św. Pawła, Studia Gdańskie XLII (2018), s. 17-38.

Reinterpretacja, Słownik Języka Polskiego, [dostęp: 14.11.2021: https://sjp.pwn.pl/sjp/ reinterpretacja;2514633].

Rindge M.S., Mortality and Enjoyment: The Interplay of Death and Possessions in Qoheleth, The Catholic Biblical Quarterly 73 (2011), s. 65-80.

Rosik M., Rapaport I., Wprowadzenie do literatury i egzegezy żydowskiej okresu biblijnego i rabinicznego, Wrocław 2009.

Spencer F.S., To Fear and Not to Fear the Creator God: a Theological and Therapeutic Interpretation of Luke 12:4-34, Journal of Theological Interpretation 8 (2014) 2, s. 229-249.

Steele W.R., Enjoying the Righteousness of Faith in Ecclesiastes, Concordia Theological Quarterly 74 (2010), s. 225-242.

Stein R.H., Luke, The New American Commentary v. 24, Nashville 1992.

Szajnert D., Intencja i interpretacja, Pamiętnik Literacki: czasopismo kwartalne poświęcone historii i krytyce literatury polskiej 91 (2000) 1, s. 7-42.

Winter J., Opening up Ecclesiastes, Leominster 2005.

Whitwell C., The Variation of Nature in Ecclesiastes 11, Journal for the Study of the Old Testament 34 (2009) 1, s. 81-97. 